\title{
Underemployment: Consequences for the Health and Well-Being of Workers
}

\author{
Daniel S. Friedland ${ }^{1,3}$ and Richard H. Price ${ }^{2}$
}

\begin{abstract}
This paper addresses the question of how the adequacy of a person's employment status influences their health. We draw on and extend the Labor Utilization Framework to distinguish between different forms of underemployment (hours, income, skills, and status) and test their relative effects on a range of physical health and psychological well-being outcomes. Using data drawn from a nationally representative sample $(N=1,429)$ of adults of working age, we assess the concurrent effects of underemployment through a longitudinal design that controls for prior levels of health and well-being. The results indicate that underemployed workers do report lower levels of health and well-being than adequately employed workers. However, the relationship varies by both types of underemployment and indicator of health and well-being. We conclude by discussing future research to explore the relationship between underemployment and health and well-being.
\end{abstract}

KEY WORDS: employment status; underemployment; unemployment; psychological well-being; physical health; depression; longitudinal research.

\section{INTRODUCTION}

Most research on employment status and health makes a simple distinction between employment and unemployment. This simple distinction obscures the complexity of the work and health relationship. Unemployment is not always harmful and reemployment is not always restorative (Ezzy, 1993; Warr, 1987). For example, when people lose jobs that are especially stressful, they often do not experience declines in well-being (Wheaton, 1990). The quality of work plays a critical role in determining whether work is a source of well-being or cause of ill-being (Kahn, 1981). Failure to account for the quality of employment may lead to an underestimation of both the harmful effects of unemployment and the beneficial effects of high-quality employment (Dooley \& Prause, 1999).

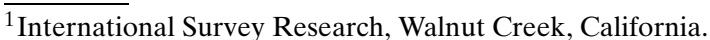

${ }^{2}$ Department of Psychology and Institute for Social Research, University of Michigan, Ann Arbor, Michigan.

${ }^{3}$ To whom correspondence should be addressed at International Survey Research, 3050 Citrus Circle, Suite 150, Walnut Creek, California, 94598.
}

Workers occupy positions along an employment continuum (Dooley, Levi, \& Fielding, 1994) or across a range of labor utilization (Clogg, 1979; Hauser, 1974; Sullivan, 1978) that includes the following statuses: unemployment, underemployment, and adequate or even overemployment. By attending to this employment continuum, researchers can develop a more accurate and detailed understanding of the relationship between employment status and health and well-being. In this paper, we explore the relationship between a variety of employment states and worker health and well-being, paying particular attention to underemployment.

\section{Defining Underemployment}

The term underemployment usually refers to a lower quality of employment relative to some standard of comparison (Feldman, 1996; Feldman, Leana, \& Turnley, 1997). However, there are almost as many operational definitions of underemployment as there are researchers studying the phenomenon. The Labor Utilization Framework (LUF; Clogg, 1979; Hauser, 
1974; Sullivan, 1978) provides a definition of underemployment that is linked to a conception of the social organization of the economy. According to the LUF, underemployment is defined in terms of the adequacy of the exchange within the labor market between the household (usually operationalized, as in the present study, by such measures as individual worker's hours and income) and the economy, and fairness is the criterion used to determine the adequacy of the exchange. Judgments regarding the adequacy of the exchange are made with the frame of reference being a minimally adequate exchange relative to social norms. From this perspective, the exchange can be inadequate along three dimensionshours of work, income from work, and skill use during work-that correspond to the core rewards provided by the economy. According to the LUF, workers may be underemployed in one of three ways: involuntary part-time work, low-income work, and skill mismatch.

Although the definition provided by the LUF is parsimonious and relatively comprehensive, it neglects a critical labor market reward-social status. Workers do not simply look for hours, income, and opportunities for skill use when entering the labor market. Jobs also provide people with the opportunity to claim certain statuses in society (Callero, 1994). Burris (1983) found that many underemployed college graduates felt they were denied the high-status positions that their education should have afforded them. Though concerned with opportunities to use their skills, the workers in Burris' study were equally concerned about reaping the status rewards their educational and familial backgrounds should afford them.

We define underemployment according to an expanded version of the LUF. People may be underemployed by hours, by income, by skills, or by status. People are "hours-underemployed" if they are involuntarily working less than full-time. People are "income-underemployed" if their job would not provide them with a livable wage even if they worked full-time. People are "skill-underemployed" when their job does not afford them the opportunity to put their skills and training to use. Finally, people are "status underemployed" when their job provides less occupational status than expected on the basis of their background.

\section{Underemployment and Health: The State of Knowledge}

There is a widely held assumption that underemployed workers have lower levels of health and well-being than adequately employed workers. Unfortunately, there are few scientific studies that assess the validity of that assumption. In contrast to the voluminous literature on the effects of unemployment on health and well-being (see Dooley, Fielding, \& Levi, 1996, for a review), there are only a handful of studies that have explicitly assessed the relationship between underemployment and health and well-being.

The majority of research about underemployment and health involves cross-sectional research designs. The results of this research provide mixed support for the assumption that underemployment is harmful for the health and well-being of workers. A number of studies show that underemployment is related to lower levels of health and well-being across a variety of indicators including job satisfaction (Burris, 1983; Kahn \& Morrow, 1991), depression (Beiser, Johnson, \& Turner, 1993; Herzog, House, \& Morgan, 1991; Johnson \& Johnson, 1996), life satisfaction (Feldman \& Turnley, 1995), self-esteem (Johnson, 1986), and physical health (Herzog et al., 1991). At the same time, other studies show that underemployment is unrelated to many of the same indicators of health and well-being, including life satisfaction (Burke, 1998; Feldman \& Turnley, 1995; Herzog et al., 1991), job satisfaction (Kahn \& Morrow, 1991), depression (Beiser et al., 1993), self-esteem (Johnson, 1986), and physical health (Johnson \& Johnson, 1997).

Although these cross-sectional studies are suggestive, they do not provide a solid basis of knowledge. The statistical associations between underemployment and health may result from any of the following underlying causal conditions: (1) underemployment affects health; (2) health affects the probability that a person will be underemployed; and (3) an unmeasured third variable affects both underemployment and health (Zapf, Dormann, \& Frese, 1996).

The few available longitudinal studies of underemployment and health and well-being address some of the concerns about spuriousness and highlight the complexity of the causal relationship. Interestingly, all of these longitudinal studies involve samples of individuals who are less than 30 years old. The literature suggests that skill underemployment affects the health and well-being of workers. Workers who experience skill underemployment approximately 2 years after they leave high school report more depressive symptoms, lower life satisfaction, a more external control orientation, and lower perceived competence 
than do their adequately employed peers (O'Brien $\&$ Feather, 1990). In addition, skill-underemployed workers became more depressed and more externally control oriented during those 2 years. The differences in life satisfaction and perceived competence between adequately employed and skill-underemployed workers stem from improvements that result from adequate employment rather than decrements that arise from underemployment. These results were obtained after controlling for initial levels of health and well-being.

Income and hours underemployment have also been shown to affect the health and well-being of workers. Workers who become hours- or incomeunderemployed after leaving high school report lower self-esteem than those who become adequately employed (Prause \& Dooley, 1997). Research suggests that these differences are due to larger increases in self-esteem among adequately employed workers rather than decreases in self-esteem among underemployed workers (Dooley \& Prause, 1995; Prause \& Dooley, 1997). Workers who experience chronic hours or income underemployment report increases in symptoms of alcohol abuse (Dooley \& Prause, 1998). The relationship between underemployment and alcohol abuse may be life course dependent, because these effects were not replicated in analyses involving the same sample 4 years later in their lives. Finally, workers who move from adequate employment into income underemployment experience increases in depression; movement into hours underemployment does not increase depression (Dooley \& Prause, 1999).

These findings highlight several points of departure for this research. First, existing research demonstrates that the relationship between underemployment and health varies by type of underemployment and indicator of health and well-being. The majority of existing studies focuses on skill underemployment and neglects hours, income, and status underemployment. In this paper, we explore the relationships between the four types of underemployment and multiple indicators of health and well-being. Second, it is important to minimize the possibility of obtaining spurious relationships due to the unmeasured influence of prior health and well-being. Therefore, we employ a longitudinal design. Third, the few longitudinal studies focus on a population of recent school leavers. Results from those studies indicate that the relationship between underemployment and health may change as workers enter their mid-twenties. In an effort to generalize findings to a broader population, we draw on an adult sample (ages $25+$ ) representative of the U.S. population.

\section{Underemployment and Health: Theoretical Underpinnings}

We view underemployment as a potential social stressor that places demands on workers and may compromise their health and well-being. Social stress is arousal due to an imbalance between perceived environmental demands and perceived capacity to respond to those demands (McGrath, 1970). The notion of imbalance is particularly important, because it cues our attention to situations of both overload and underload. Stress can emerge from situations where demands either exceed or do not meet a person's response capacity. Further, stressors are internally or externally derived stimuli that cause the experience of social stress. Social stressors can take one of two general forms: eventful and chronic stressors (Avison \& Turner, 1988; Pearlin, Menaghan, Lieberman, \& Mullan, 1981). Eventful stressors are short-lived stimuli (e.g., job loss). Chronic stressors represent more enduring problems. We argue that underemployment is often experienced as a chronic stressor.

When examining the relationship between stress and health, one needs to attend to the specificity of reactions to stress and the timing of stress experience in relation to health and well-being measurement. Researchers need to examine the effects of stress across a variety of outcomes in order to more closely approximate the true consequences of a stressor for health and well-being (Aneshensel, Rutter, \& Lachenbruch, 1991). By focusing on single disorders or indicators of health, researchers may seriously under- or overestimate the consequences of underemployment for health. In our research, we examine the relationship between underemployment and a range of both physical and mental health indicators.

The recency of stressful experience is particularly important when examining the relationship between stress and health. More recent events and chronic strains are more consequential for depression than for events that occurred more than 3 months before the interview (Avison \& Turner, 1988). Building from the literature discussed so far, we hypothesize that underemployed workers will have lower levels of physical health and psychological well-being than adequately employed workers. 


\section{METHODOLOGY}

\section{Data}

We analyzed data from the Americans' Changing Lives (ACL) study (House, 1997) to assess the relationship between employment status and both physical health and psychological well-being. The ACL was conducted by the Survey Research Center of the University of Michigan. Three waves of data were collected over an 8-year period, with Wave 1 in 1986, Wave 2 in 1989, and Wave 3 in 1994. In this research, we used data from the panel of Waves 1 and 2 of the project.

The study population for the ACL was defined to include the U.S. household population aged 25 years and older who lived in the 48 contiguous states and did not live on military bases, in group quarters, or in institutions (for a detailed description of the design and content of the ACL, see House, 1997).

Our analyses are conducted on a subsample $(N=1,429)$ of the ACL that includes only people who were a part of the labor force during both waves of data collection. The Bureau of Labor Statistics classifies people as in the labor force if they are currently either employed or not employed but looking for paid work (i.e., unemployed). We limited the sample in this way because the central research questions concern how participation and status within the labor force relate to physical health and psychological well-being. It is important to note that these results can only be generalized to people who remain a part of the labor force over time.

In all analyses, the data were weighted to adjust for variation in probabilities of selection and in response rates. We used poststratification weights to make the weighted ACL sample correspond to the July 1986 Bureau of Census population estimates by age (25-64 vs. 65 and over), sex, and region (Northeast, Midwest, South, and West). The weights also compensated for differential nonresponse between waves. The weights do not address issues of employment status or health and well-being. Therefore, if those people who are worst off in terms of employment status or health are less likely to respond, they may be underrepresented in the sample. Such underrepresentation could limit variation in the outcome measures and lead to an underestimation of the strength of the relationship between underemployment and health. We report demographic characteristic frequencies for the weighted subsample in Table I and means and standard deviations in Table II.
Table I. Frequencies of Demographic and Employment Status Variables

\begin{tabular}{lrr}
\hline \multicolumn{1}{c}{ Variable } & Time 1 & Time 2 \\
\hline Gender & & \\
Male & $56.3 \%$ & $56.3 \%$ \\
Female & $43.7 \%$ & $43.7 \%$ \\
Race & & \\
Black & $10.5 \%$ & $10.5 \%$ \\
$\quad$ Non-Black & $89.5 \%$ & $89.5 \%$ \\
Marital status & & \\
Married & $71.6 \%$ & $72.0 \%$ \\
Not married & $28.4 \%$ & $28.0 \%$ \\
Employment status & & \\
Unemployed & $4.7 \%$ & $3.0 \%$ \\
Not adequately employed & $57.6 \%$ & $61.9 \%$ \\
$\quad$ Underemployed-hours & $5.7 \%$ & $5.2 \%$ \\
$\quad$ Underemployed-income & $7.1 \%$ & $7.4 \%$ \\
$\quad$ Underemployed-skills & $23.2 \%$ & $23.8 \%$ \\
$\quad$ Underemployed-status & $12.0 \%$ & $13.8 \%$ \\
$\quad$ Overemployed & $9.6 \%$ & $11.7 \%$ \\
Adequately employed & $37.7 \%$ & $35.1 \%$ \\
\hline
\end{tabular}

Note. All percentages are based on the weighted data $(N=1,429)$.

\section{Measures}

\section{Employment Status}

We classified respondents into one of three groups: unemployed, underemployed, and overemployed. A fourth group, adequately employed, consisted of those respondents who were not included in any of the other three groups. Consistent with $\mathrm{Bu}$ reau of Labor Statistics procedures, the unemployed group includes those people who did not have a job and were looking for work. The overemployed group includes those people who were working more than $45 \mathrm{hr}$ per week, indicated that they wanted to work fewer hours, and did not experience any type of underemployment. The underemployed group was composed of four subcategories: hours, income, skill, and status. Traditionally, applications of the LUF treat the different types of underemployment as mutually exclusive (e.g., Sullivan, 1978) and organized in a hierarchical fashion. In addition to being mutually exclusive, the types are organized in a hierarchical fashion starting with hours underemployment, continuing through income underemployment, and ending with skill underemployment. We extend this hierarchy by including status underemployment as the final level. Because of this hierarchical arrangement, we classified people into types of underemployment in a series of steps with people meeting the criteria for a lower level of underemployment being ineligible for 
Table II. Means, Standard Deviations, and Ranges for Demographic and Dependent Variables

\begin{tabular}{|c|c|c|c|c|c|c|}
\hline \multirow[b]{2}{*}{ Variable } & \multicolumn{2}{|c|}{ Mean } & \multicolumn{2}{|c|}{$\mathrm{SD}$} & \multicolumn{2}{|c|}{ Range } \\
\hline & $\mathrm{T} 1$ & $\mathrm{~T} 2$ & $\mathrm{~T} 1$ & $\mathrm{~T} 2$ & $\mathrm{~T} 1$ & $\mathrm{~T} 2$ \\
\hline Hours worked/week & 40.7 & 41.09 & 15.96 & 15.21 & $0-95$ & $0-95$ \\
\hline Age & 39.91 & 42.54 & 11.02 & 11.05 & $24-91$ & $27-94$ \\
\hline Education (years) & 13.29 & 13.29 & 2.59 & 2.59 & $0-17$ & $0-17$ \\
\hline Subjective health & 4.01 & 3.76 & 0.87 & 0.87 & $1-5$ & $1-5$ \\
\hline Functional health & 4.73 & 4.68 & 0.69 & 0.73 & $1-5$ & $1-5$ \\
\hline Chronic disease & 0.63 & 0.66 & 0.91 & 0.99 & $0-7$ & $0-8$ \\
\hline Life satisfaction & 4.01 & 5.35 & 0.87 & 1.25 & $1-5$ & $1-7$ \\
\hline Depression symptoms & 1.37 & 1.33 & 0.33 & 0.32 & $1-2.90$ & $1-2.70$ \\
\hline Positive self-concept & 3.33 & 3.41 & 0.53 & 0.51 & $1-4$ & $1.4-4$ \\
\hline Job satisfaction & 4.07 & 4.01 & 0.82 & 0.83 & $1-5$ & $1-5$ \\
\hline \multicolumn{7}{|c|}{$\begin{array}{l}\text { Note. All of the descriptive statistics and sample sizes are based on the } \\
\text { weighted data. For the variable Job Satisfaction (not available for the unem- } \\
\text { ployed), the sample size ranged from } 1,362 \text { at Time } 1 \text { to } 1,386 \text { at Time } 2 \text {. For } \\
\text { all of the other variables, the sample sizes for both times ranged from } 1,422 \\
\text { to } 1,429 \text {. }\end{array}$} \\
\hline
\end{tabular}

inclusion in other underemployment groups (i.e., a respondent classified as hours underemployed cannot be classified as skill underemployed). Below, we specify how we measured the different types of underemployment.

\section{Hours-Based Underemployment}

This type of underemployment represents involuntary part-time employment. We classified people as involuntarily part-time employed when they met the following criteria: (1) they are currently working fewer than $35 \mathrm{hr}$ per week and (2) they indicate that they would like to work more hours per week.

\section{Income-Based Underemployment}

This type of underemployment represents whether a respondent's job-related income would be above $125 \%$ of the Poverty Threshold, for an individual worker under the age of 65 , if they worked $35 \mathrm{hr}$ per week for 50 weeks out of the year. To create this variable, we drew upon the respondent's report of job-related earnings. We first converted each report to an hourly wage. Then, we multiplied that wage by 35 (hr/week) and 50 (weeks/year). Finally, we adjusted for the number of hours the respondent works per week by multiplying the wage by 35 and dividing by the number of hours they work per week. This final adjustment helps to correct both for those individual who are below $125 \%$ of the threshold due to low hours and for those individuals who are above $125 \%$ of the threshold due to high hours. Respondents who were hours-unemployed were not eligible to be classified as income underemployed.

\section{Skill-Based Underemployment}

This variable represents whether a respondent is overeducated for their current occupation. We created this variable in three steps. First, we clustered occupations on the basis of the modal education and training path people take to achieve proficiency. Second, we linked these clusters with specific education cut-off values. Third, we compared a person's educational attainment to the cut-off and classified people as skill-based underemployed if their educational attainment was higher than the cut-off value. Below, we describe how we clustered occupations and assigned cut-off values.

We drew the framework for clustering occupations from work conducted by the Bureau of Labor Statistics (Walsh, 1995-1996). Walsh and colleagues at the Bureau of Labor Statistics identified 11 clusters based on education, training, and experience criteria. Walsh and colleagues at the Bureau of Labor Statistics identified 11 clusters with the following education, training, and experience criteria: (1) first professional degree (e.g., MD, JD), (2) doctoral degree, (3) Master's degree, (4) work experience plus a Bachelor's degree or higher, (5) Bachelor's degree, (6) Associate's degree, (7) postsecondary vocational training, (8) work experience, (9) long-term 
on-the-job training, (10) moderate length on the job training, and (11) short-term on-the-job training. We could only partially apply this framework, because the ACL measures total years of education $(0-17+)$ yet lacks essential information about on the job training, and level of occupation-relevant work experience.

Using the ACL's measure of total years of education, we collapsed the 11 clusters into four: (1) Bachelor's degree or higher, (2) Associate's degree, (3) postsecondary vocational training, and (4) on-thejob training or experience. We chose the following educational cut-off values for these clusters: (1) 17 years of schooling for occupations linked with a Bachelor's or higher, (2) 14 years of schooling for those linked with an Associate's degree, and (3) 13 years of schooling for those linked with postsecondary vocational education. Following previous applications of the LUF, people with 12 years of education or less were not eligible to be classified as skill underemployed (Sullivan, 1978). In addition, respondents who were classified as hours- or income-underemployed were not eligible to be classified as skill-underemployed.

\section{Status-Based Underemployment}

This variable represents whether respondents hold occupations of lower socioeconomic status than would be predicted by their educational attainment. We made these classifications by using a procedure previously described in the literature (Johnson, 1986). First, we created a variable that indicated a person's expected Duncan's SEI based on their educational attainment. To create this variable, we (a) regressed Duncan's SEI scores on educational attainment and the square of educational attainment, and then (b) used the unstandardized regression coefficients from this analysis to compute an expected Duncan's SEI for each individual in the sample. Second, we created a deviation score that indicates the discrepancy of a person's actual SEI from that predicted from their educational attainment. Finally, we classified people as status underemployed when their deviation score was greater than $1(S D)$ below the mean deviation score. Respondents who were classified as hours-, income-, or skill-underemployed were not eligible to be classified as status-underemployed.

\section{Physical Health}

Because previous research and theory indicates that physical health is a multidimensional construct
(Liang, 1986), we used three distinct measures of physical health for this research: subjective health, functional health, and chronic disease. We describe these measures below.

We measured subjective health with a single item that asked people to rate their health at the present time. Respondents rated this item on a 5-point scale from excellent to poor. We coded the item so that higher scores indicate greater subjective health. This item has been used prevalently in the public health literature and is predictive of mortality (Idler \& Kasl, 1991). We measured functional health with a single item that asked people to rate the degree that their health or health-related problems interfered with their daily activities. Respondents rated this item on a 5-point scale from a great deal to not at all with higher scores representing greater functional health. Finally, we measured chronic disease by counting the number of major chronic conditions people reported experiencing during the past year. The list covered a range of major and more minor chronic medical conditions: arthritis, rheumatism, lung disease, hypertension, heart attack or hear trouble, diabetes, cancer/malignant tumor, foot problems, stroke, fractures or broken bones, and loss of urine beyond one's control.

\section{Psychological Well-Being}

Like physical health, psychological well-being is also a multidimensional construct (Diener, 1984; Ryff \& Keyes, 1995; Warr, 1987). We use a variety of indicators of both general well-being (i.e., life satisfaction, depression symptoms, and positive self-concept) and context-specific well-being (i.e., job satisfaction).

We measured life satisfaction, using a single item (Andrews \& Withey, 1976). Slightly different items were used in the different waves. At Wave 1, respondents rated their satisfaction with their life as a whole on a 5-point scale ranging from completely satisfied to not at all satisfied. At Wave 2, respondents rated their satisfaction with their life as a whole on a 7-point scale ranging from completely satisfied to completely dissatisfied.

We measured depression symptoms, using 11 items from the Center for Epidemiological Studies Depression (CES-D) Scale (Radloff, 1977). We coded the items so that higher scores indicate higher levels of depressive symptomatology $(\alpha=.83)$. Research indicates that the 11-item version of the CES-D is comparable to the original version in both precision and 
the symptom dimensions it taps (Kohout, Berkman, Evans, \& Cornoni-Huntley, 1993).

We measured positive self-concept, using five items drawn from widely used measures of mastery (Pearlin et al., 1981) and self-esteem (Rosenberg, 1965). The resulting index represents the degree that people feel worthwhile and capable of influencing the world around them. Respondents were asked to report how strongly they agreed or disagreed with each of the following statements: "I take a positive attitude toward myself," "At times I think I am no good at all," "All in all, I am inclined to feel that I am a failure," "Sometimes I feel that I am being pushed around in life," "There is really no way I can solve the problems I have." Each item has a 4-point response scale from strongly agree to strongly disagree. We coded the items so that higher scores indicated higher levels of positive self-concept $(\alpha=.67)$.

We measured job satisfaction, using an index composed of the following two items: (1) how much do you enjoy doing that work and (2) how satisfied are you with your job? Each item has a 5-point response scale. We coded items so that higher scores indicated higher levels of job satisfaction $(\alpha=.77)$.

\section{Demographic Characteristics}

We included a number of demographic characteristics, with documented relationships to underemployment and/or physical health and psychological well-being, in all multivariate analyses. More specifically, we included the following characteristics in the analyses (a) age (continuous), (b) gender (female = $1)$, (c) race (non-Black $=1)$, (d) education (continuous), (e) marital status ( $1=$ married $)$, and (f) number of hours worked per week (continuous).

\section{RESULTS}

To test the hypotheses that underemployed workers will have lower levels of physical health and psychological well-being than adequately employed workers, we ran a series of hierarchical multiple regression analyses. To rule out the possibility that the concurrent relationship is due to the effects of prior health on both current health and current employment status, we included the $\mathrm{T} 1$ measure of health and well-being in the equation. We estimated a separate regression equation for each health and well-being outcome. The results for physical health are presented in Table III and those for psychological well-being are presented in Table IV.
Table III. Multiple Regression of T2 Physical Health on T2 Employment Status Net of T1 Physical Health

\begin{tabular}{lccc}
\hline \multicolumn{1}{c}{ Variable } & $\begin{array}{c}\text { Subjective } \\
\text { health }\end{array}$ & $\begin{array}{c}\text { Functional } \\
\text { health }\end{array}$ & $\begin{array}{c}\text { Chronic } \\
\text { disease }\end{array}$ \\
\hline T1 physical health (stability) & $.502^{* * *}$ & $.393^{* * *}$ & $.549^{* * *}$ \\
Sex $(1=$ female $)$ & -.017 & .032 & $.059^{*}$ \\
Age & $-.051^{*}$ & $-.099^{* * *}$ & $.178^{* * *}$ \\
Race $(1=$ non-Black $)$ & .011 & $.042^{\dagger}$ & -.026 \\
Education & $.051^{\dagger}$ & $.051^{\dagger}$ & .030 \\
Marital status $(1=$ married) & -.027 & .010 & .018 \\
\# hours worked/week & .031 & .023 & .022 \\
Unemployment & -.020 & $-.103^{* *}$ & $.061^{*}$ \\
Underemployment-hours & -.024 & -.044 & .013 \\
Underemployment-income & -.025 & $-.054^{*}$ & -.014 \\
Underemployment-skills & -.020 & -.045 & -.011 \\
Underemployment-status & -.024 & $-.070^{*}$ & $.076^{* *}$ \\
Overemployment & .019 & -.017 & $.049^{*}$ \\
Adjusted $R^{2}$ & $.282^{* * *}$ & $.207^{* * *}$ & $.404^{* * *}$ \\
$N$ & 1,341 & 1,339 & 1,341 \\
\hline
\end{tabular}

Note. This table presents standardized regression coefficients. All continuous variables (dependent variables, T1 physical health, age, education, hours/week) were standardized before being input into the equation.

${ }^{\dagger} p<.10 .{ }^{*} p<.05 .{ }^{* *} p<.01 .^{* * *} p<.001$.

\section{Employment Status and Physical Health: Concurrent Relationship}

Our results provide some support for the hypothesis that underemployment is related to lower levels of physical health. We find that underemployment is related to two of the three indicators of physical health. Of the four types of underemployment, income and status are the only ones related to physical health. People who are status-underemployed report more chronic disease and less functional health than do adequately employed workers. People who are incomeunderemployed report less functional health than do adequately employed workers.

Similar to the findings concerning underemployment, the experience of both unemployment and overemployment are related to lower levels of physical health. Unemployed workers report lower levels of functional health and more chronic disease. Overemployed workers report more chronic disease.

\section{Employment Status and Psychological Well-Being: Concurrent Relationship}

The results concerning income and status underemployment provide some support for the hypothesis that underemployment is related to lower levels of psychological well-being. Those workers 
Table IV. Multiple Regression of T2 Psychological Well-Being on T2 Employment Status Net of T1 Psychological Well-Being

\begin{tabular}{lcccc}
\hline \multicolumn{1}{c}{ Variable } & Life satisfaction & Depression symptoms & Positive self-concept & Job satisfaction \\
\hline T1 psychological well-being & $.351^{* * *}$ & $.454^{* * *}$ & $.530^{* * *}$ & $.459^{* * *}$ \\
Sex (1 = female) & $-.047^{\dagger}$ & -.002 & $-.041^{\dagger}$ & -.012 \\
Age & .029 & -.034 & .009 & .042 \\
Race (1 = non-Black) & $.053^{*}$ & $-.046^{\dagger}$ & .024 & -.026 \\
Education & .005 & $-.056^{*}$ & .026 & -.026 \\
Marital status (1 = married) & $.062^{*}$ & -.020 & .015 & .014 \\
\# hours worked/week & $-.077^{*}$ & .022 & -.020 & $.107^{* *}$ \\
Unemployment & $-.099^{* *}$ & $.052^{\dagger}$ & $-.049^{\dagger}$ & NA \\
Underemployment-hours & -.040 & .038 & $-.043^{\dagger}$ & $.075^{* *}$ \\
Underemployment-income & .029 & $.079^{* *}$ & $-.046^{\dagger}$ & .033 \\
Underemployment-skills & .034 & -.033 & .041 & -.015 \\
Underemployment-status & -.007 & .044 & $-.049^{\dagger}$ & -.045 \\
Overemployment & .048 & $-.060^{*}$ & .034 & $-.063^{*}$ \\
Adjusted $R^{2}$ & .153 & .258 & .324 & .224 \\
$N$ & 1,336 & 1,336 & 1,329 & 1,253 \\
\hline$N$
\end{tabular}

Note. This table presents standardized regression coefficients. All continuous variables were standardized before being input into the equation.

${ }^{\dagger} p<.10{ }^{*} p<.05 .{ }^{* *} p<.01 .{ }^{* * *} p<.001$.

who are income-underemployed report higher levels of depression symptoms and lower positive selfconcepts than do adequately employed workers. Status-underemployed workers also report higher levels of depression symptoms and lower levels of positive self-concept.

The results concerning hours underemployment inconsistently support the hypothesis and the results for skill underemployment do not support the hypothesis. Hours-underemployed workers report lower levels of positive self-concept. However, they also report high levels of job satisfaction. Skill underemployment is not significantly related to any of the indicators of health and well-being.

Unemployment is related to lower levels of health and well-being across all indicators of health and well-being. Unemployed respondents report lower levels of life satisfaction and positive selfconcept. In addition, they report higher levels of depression symptoms. In contrast to the results for unemployment, overemployment is related to lower levels of depression symptoms. Overemployed workers do, however, report lower levels of job satisfaction.

\section{DISCUSSION}

Taken as a whole, these results provide moderate support for the hypothesis that underemployed workers will experience lower levels of health and wellbeing than adequately employed workers. Underemployment is related to lower levels of four of seven indicators of health and well-being. However, the relationship between underemployment and health and psychological well-being varies by both types of underemployment and indicator of health and wellbeing. Rather than speaking in general terms, researchers would be well served by specifying the type of underemployment and the indicator of health and well-being when describing their relationship. The results across these types of underemployment and indicators of health are summarized in Table V.

Table V. Summary of Concurrent Effects of Underemployment on Health and Well-Being

\begin{tabular}{|c|c|c|c|c|c|c|c|}
\hline $\begin{array}{c}\text { Type of } \\
\text { underemployment }\end{array}$ & $\begin{array}{l}\text { Subjective } \\
\text { health }\end{array}$ & $\begin{array}{l}\text { Functional } \\
\text { health }\end{array}$ & $\begin{array}{l}\text { Chronic } \\
\text { disease }\end{array}$ & $\begin{array}{c}\text { Life } \\
\text { satisfaction }\end{array}$ & $\begin{array}{c}\text { Depression } \\
\text { symptoms }\end{array}$ & $\begin{array}{c}\text { Positive } \\
\text { self-concept }\end{array}$ & $\begin{array}{c}\text { Job } \\
\text { satisfaction }\end{array}$ \\
\hline Hours & & & & & & $*$ & - \\
\hline Income & & $* *$ & & & $* *$ & $*$ & \\
\hline \multicolumn{8}{|l|}{ Skill } \\
\hline Status & & $* *$ & $* *$ & & & * & \\
\hline
\end{tabular}


The hypothesis linking underemployment to health and well-being is moderately supported for status and income underemployment. Each type is related to three indicators of health and well-being. People who experience status underemployment report that their health interferes more with their activities, they experience more chronic disease, and have lower positive self-concept than adequately employed workers. Income-underemployed workers also report that their health interferes more with their activities, that they experience more depression symptoms, and have lower positive self-concept than adequately employed workers. The results for income underemployment follow other studies in the literature that indicate income underemployment is linked to depression (Dooley \& Prause, 1999) and self-esteem (Prause \& Dooley, 1997).

The hypothesis is very weakly supported for hours underemployment. This type of underemployment is unrelated to any of the indicators of physical health. Hours underemployment is related to several indicators of psychological well-being. Workers who are hours-underemployed do report lower levels of positive self-concept than adequately employed workers. In contrast to the hypothesis, hoursunderemployed workers report higher levels of job satisfaction. This latter finding may be an artifact of the way hours underemployment was operationalized. To be classified as hours underemployed, the person needed to indicate that they wanted to work more hours at their job. One reason people may want to work more hours is that they are more satisfied with their jobs. The results for skill underemployment provide no support for the hypothesis. Skill underemployment is not significantly related to any of the seven indicators of health and well-being.

Taken as a whole, these results indicate that certain types of underemployment have a modest negative effect on certain types of health and well-being. Though modest, the effects are comparable in size to those generally found in longitudinal studies of stress and health. Given the stability of health over time and the large number of stressors known to affect health, the size of the relationship between any one stressor and health is usually small (Zapf et al., 1996).

Although the results provide only moderate support for the proposed relationship between underemployment and health and well-being, they demonstrate that unemployment is consistently related to lower levels of health and well-being. Across five of the six relevant outcome measures, unemployed people reported poorer health and well-being than ad- equately employed people. In contrast to the consistent results for unemployment, the results for overemployment are more varied. Overemployed workers report more chronic disease and lower job satisfaction than adequately employed workers. At the same time, overemployed workers also report lower levels of depression symptoms. Similar to the relationship between hours underemployment and job satisfaction, the relationship between overemployment and job satisfaction may be an artifact of the way the status was operationalized. To be classified as overemployed respondents needed to indicate that they would like to work fewer hours.

Finally, these results underscore the importance of controlling for prior levels of the dependent variable when examining the relationship between underemployment and health and well-being. Failure to control for previous levels of health and well-being will lead researchers to overestimate the effects of different types of underemployment on health and well-being. The overestimation appears particularly problematic for hours underemployment that was often related to health before $\mathrm{T} 1$ health was controlled and rarely related to health after $\mathrm{T} 1$ health was controlled.

\section{Limitations}

This study possesses some limitations that may have influenced the results and the validity of our interpretations of the findings. These limitations include variable operationalization and sample size. The limited support for hypotheses concerning the relationship between skill underemployment and health may be due to the limitations of the measure. Our operationalization of skill underemployment is based on an assumption that education provides people with a set of skills that they are able to put into practice on their jobs. Critics argue that measures of overeducation do not adequately capture skill utilization (Halaby, 1994; Smith, 1986). Previous research indicates that overeducation measures of skill utilization are much less effective than direct measures of skill utilization at predicting job satisfaction (Kahn \& Morrow, 1991). Future research should attempt to measure skill underemployment more directly by asking people about the fit between their skills and the requirements of their jobs (Halaby, 1994; Kahn \& Morrow, 1991).

The second limitation stems from the sampling frame of the ACL. Because the ACL was primarily 
designed to study the effects of aging on health, there are a large number of respondents who do not participate in the labor market. Therefore the sample available for our research is smaller than the scope of the ACL would suggest. Although there are over 1,400 respondents in our sample, there are very few respondents who are classified as hours- or incomeunderemployed. Because of the limited number of respondents who have these experiences, there is low statistical power (Cohen, 1992) for tests involving the relationship between hours or income underemployment and health and well-being. Future research should either draw upon larger samples or oversample for people who are hours- or income-underemployed, in order to ensure adequate statistical power.

\section{Future Research Directions}

Several promising areas for future research can expand our theoretical understanding of how, why, and under what conditions underemployment is related to the health and well-being. In particular, the following issues warrant attention: (1) specifying the causal direction of the relationship between underemployment and health, (2) specifying the process through which underemployment and health are related, and (3) investigating the dynamics of the relationship between employment status and health over time. This enhanced theoretical and empirical understanding will be essential to specify effective interventions targeted at preventing the negative health effects of underemployment.

Establishing that a relationship exists between underemployment and health and well-being is not sufficient to claim that underemployment is the cause of poor health and well-being. As noted earlier, the statistical association could represent one or both of two potential causal pathways: social causation and social selection (Dooley, Catalano, \& Hough, 1992; Ross \& Mirowski, 1995). Some studies find clear support for the social causation perspective (Dooley \& Prause, 1997a; O'Brien \& Feather, 1990). Other studies provide evidence that supports the social selection argument (Dooley \& Prause, 1997b; Leana \& Feldman, 1995). Future research should examine the degree that different types of underemployment cause or are caused by health and psychological well-being.

Existing research on underemployment and health rarely focuses on the processes through which different types of underemployment are related to health and psychological well-being. One approach to specifying process is to explore the issue of subgroup vulnerability. Research suggests that workers may be differentially vulnerable to the effects of underemployment. For example, in a study of East Asian immigrants and Vancouver residents, underemployment was related to higher levels of depression for Vancouverites but not for the immigrants (Beiser et al., 1993). Other research suggests that older workers and workers with greater external control orientations are especially vulnerable to the effects of underemployment (House \& Harkins, 1975). By studying these issues of subgroup vulnerability, researchers may begin to understand the social and psychological mechanisms linking underemployment and health and well-being.

Researchers have explained this differential experience of subgroups by arguing that the different groups attach different meaning to their work role experiences. The meaning-making explanation of group differences evokes many of the same ideas as recent attempts to integrate identity theory and social stress theory (Burke, 1991; Krause, 1994; Thoits, 1991). The effects of underemployment on health and well-being may depend on the types of judgments people draw about themselves as a result of the underemployment experience. People who rely heavily on the work role for either self-definition or resources to help them fulfill other role obligations may be especially vulnerable to the effects of underemployment. For these people, the experience of underemployment is very likely to call into question certain fundamental expectations they have about themselves and their ability. On the basis of this reasoning, future research could examine whether the relationship between the types of underemployment and health and well-being is moderated by age, gender, whether the person is a part of a dual earner household, and the number of roles the person holds.

Another approach to specifying the processes linking underemployment and well-being is to test potential mediators of the relationship between types of underemployment and indicators of health and wellbeing. Different mediators may account for the relationship for different types of underemployment. For example, hours and income underemployment are likely to expose workers to financial stress. The experience of financial stress has been linked to higher levels of depression and other indicators of affective ill-being (Ross \& Huber, 1985; Vinokur, Price, \& Caplan, 1996). The deprivation associated with financial stress may also affect physical health through both nutrition and use of health care facilities (Beasley, 
1991; Price, 1990). Therefore, financial stress may mediate the relationship between hours and income underemployment and health and well-being.

Another example is the observation that people who experience status underemployment are more likely to occupy lower status positions. Lower status occupations offer less self-direction (Kohn \& Schooler, 1983) and job decision latitude (Karasek \& Theorell, 1990) to workers. Research has consistently shown that workers experience lower levels of stress and are less affected by stress when they have control over factors in their work environments (Karasek \& Theorell, 1990; Sutton \& Kahn, 1986). Therefore, the effects of status underemployment may be mediated by job decision latitude.

Future research should also explore the relationship between underemployment and health across various time periods to begin to understand when the effect occurs and what form the relationship between underemployment and well-being takes over time. There are many different models of the nature of the stress-strain relationship over time (Zapf et al., 1996). One model holds that there is a linear relationship between stress and strain. In this model, the effects of stress occur immediately, increase as the stressor intensifies, and decrease as the stressor dissipates. Another model holds that there is an initial linear relationship between stressors and outcomes, but over time the individual adjusts to the stressor and the effects diminish although the stressor is still present. A third model holds that the effects of stress only occur after a period of exposure to the stressor and persist even after the stressor is removed. A fourth model extends the third by entertaining the possibility that the effect of the stressor may continue to increase even after it is removed because the stressor has made the individual more vulnerable to other stressors in the environment. A final model holds that the effects of stress occur long after exposure to the stressor. By testing the validity of each of these models for the relationship between underemployment and health, researchers can create a much more nuanced understanding of the connection between types of underemployment and health. In fact, research may indicate that the form of the underemployment and health relationship varies by type of underemployment and types of outcome.

In conclusion, our results indicate that underemployment does produce adverse consequences for the health and psychological well-being of workers. However, those consequences are neither as powerful nor as consistent as common assumptions would lead one to believe. The relationship between underemployment and health varies considerably by both types of underemployment and indicator of health and well-being, as Kalleberg (2000) suggests. Therefore researchers should frame their discussions around specific types of underemployment rather than describing the general effects of underemployment. Critical questions remain to be answered regarding why underemployment and health are related and the form that relationship takes over time.

\section{ACKNOWLEDGMENTS}

We thank Amiram Vinokur, Debby Carr, and Richard Saavedra for their feedback on this work when it was a part of the lead author's dissertation at the University of Michigan. In addition, we thank two anonymous $A J C P$ reviewers and, especially, special issue editor David Dooley for constructive feedback on earlier drafts that significantly improved this paper.

This paper was supported in part by the National Institute of Mental Health Grant P30MH38330 to the Michigan Prevention Research Center, Institute for Social Research, University of Michigan.

\section{REFERENCES}

Andrews, F. M., \& Withey, S. B. (1976). Social indicators of well-being: Americans' perceptions of life quality. New York: Plenum.

Aneshensel, C. S., Rutter, C. M., \& Lachenbruch, P. A. (1991). Social structure, stress, and mental health: Competing conceptual and analytic models. American Sociological Review, 56, 166178.

Avison, W. R., \& Turner, R. J. (1988). Stressful life events and depressive symptoms: Disaggregating the effects of acute stressors and chronic strains. Journal of Health and Social Behavior, $29,253-264$.

Beasley, J. D. (1991). The betrayal of health: The impact of nutrition, environment, and lifestyle on illness in America. New York: Times Books.

Beiser, M., Johnson, P. J., \& Turner, R. J. (1993). Unemployment, underemployment and depressive affect among Southeast Asian refugees. Psychological Medicine, 23, 731-743.

Burke, P. J. (1991). Identity processes and social stress. American Sociological Review, 56, 836-849.

Burke, R. J. (1998). Work stressors among recent business school graduates. Stress Medicine, 14, 83-89.

Burris, B. H. (1983). The human effects of underemployment. Social Problems, 31, 96-110.

Callero, P. L. (1994). From role-playing to role-using: Understanding role as resource. Social Psychology Quarterly, 57, 228-243.

Clogg, C. C. (1979). Measuring underemployment: Demographic indicators for the United States. New York: Academic Press.

Cohen, J. (1992). A power primer. Psychological Bulletin, 112, 155159. 
Diener, E. (1984). Subjective well-being. Psychological Bulletin, 85, 542-575.

Dooley, D., Catalano, R., \& Hough, R. (1992). Unemployment and alcohol disorder in 1910 and 1990: Drift versus social causation. Journal of Occupational and Organizational Psychology, 65, 277-290.

Dooley, D., Fielding, J., \& Levi, L. (1996). Health and unemployment. Annual Review of Public Health, 17, 449-465.

Dooley, D., Levi, L., \& Fielding, J. (1994). Health and the employment continuum. Paper presented at the California Wellness Foundation Conference on Unemployment and Health, Santa Monica, CA.

Dooley, D., \& Prause, J. (1995). Effect of unemployment on school leaver's self-esteem. Journal of Occupational and Organizational Psychology, 68, 177-192.

Dooley, D., \& Prause, J. (1997a). Effect of favorable employment change on alcohol abuse: One-and five-year follow-ups in the National Longitudinal Survey of Youth. American Journal of Community Psychology, 25, 787-807.

Dooley, D., \& Prause, J. (1997b). Effect of students' self-esteem on later employment status: Interactions of self-esteem with gender and race. Applied Psychology: An International Review, 46, 175-198.

Dooley, D., \& Prause, J. (1998). Underemployment and alcohol misuse in the National Longitudinal Survey of Youth. Journal of Studies on Alcohol, 59, 669-680.

Dooley, D., \& Prause, J. (1999). Underemployment as disguised unemployment and its social costs. Paper presented at the APA-NIOSH Interdisciplinary Conference on Work, Stress, and Health '99: Organization of Work in a Global Economy, Baltimore.

Ezzy, D. (1993). Unemployment and mental health: A critical review. Social Science and Medicine, 37, 41-52.

Feldman, D. C. (1996). The nature, antecedents, and consequences of underemployment. Journal of Management, 22, 385407.

Feldman, D. C., Leana, C. R., \& Turnley, W. H. (1997). A relative deprivation approach to understanding underemployment. In C. L. Cooper \& D. M. Rousseau (Eds.), Trends on Organizational Behavior (Vol. 4, pp. 43-60).

Feldman, D. C., \& Turnley, W. H. (1995). Underemployment among recent business college graduates. Journal of Organizational Behavior, 16, 691-706.

Halaby, C. N. (1994). Overeducation and skill mismatch. Sociology of Education, 67, 47-59.

Hauser, P. M. (1974). The measurement of labour utilization. Malayan Economic Review, 19, 1-17.

Herzog, A. R., House, J. S., \& Morgan, J. N. (1991). Relations of work and retirement to health and well-being in older age. Psychology and Aging, 6, 202-211.

House, J. S. (1997). Americans' changing lives: Waves I and II, 1986 and 1989 (Computer file, ICPSR version). Ann Arbor: University of Michigan, Survey Research Center (producer), 1994. Ann Arbor: Inter-university Consortium for Political and Social Research (distributor), 1997.

House, J. S., \& Harkins, E. B. (1975). Why and when is status inconsistency stressful? American Journal of Sociology, 81, 395412.

Idler, E. L., \& Kasl, S. (1991). Health perceptions and survival: Do global evaluations of health status really predict mortality? Journal of Gerontology: Social Sciences, 46, S55S65.

Johnson, G. J. (1986). The effects of underemployment and being underpaid on psychological functioning among working men (Doctoral dissertation, University of Michigan, 1986). Dissertation Abstracts International, 47(6-A) 2339.

Johnson, G. J., \& Johnson, W. R. (1996). Perceived overqualification and psychological well-being. Journal of Social Psychology, 136, 435-445.
Johnson, G. J., \& Johnson, W. R. (1997). Perceived overqualification, emotional support, and health. Journal of Applied Social Psychology, 27, 1906-1918.

Kahn, R. L. (1981). Work and Health. New York: Wiley.

Kahn, L. J., \& Morrow, P. C. (1991). Objective and subjective underemployment relationships to job satisfaction. Journal of Business Research, 22, 211-218.

Kalleberg, A. L. (2000). Nonstandard employment relations: Parttime, temporary and contract work. Annual Review of Sociology, 26, 341-365.

Karasek, R., \& Theorell, T. (1990). Healthy work: Stress, productivity, and the reconstruction of working life. New York: Basic Books.

Kohn, M. L., \& Schooler, C. (1983). Work and personality: An inquiry into the impact of social stratification. Norwood, NJ: Ablex.

Kohout, F. J., Berkman, L. F., Evans, D. A., \& Cornoni-Huntley, J. (1993). Two shorter forms of the CES-D depression symptoms index. Journal of Aging and Health, 5, 179-193.

Krause, N. (1994). Stressors in salient social roles and well-being in later life. Journal of Gerontology, 49, 137-148.

Leana, C. R., \& Feldman, D. C. (1995). Finding new jobs after a plant closing: Antecedents and outcomes of the occurrence and quality of reemployment. Human Relations, 48, 13811401.

Liang, J. (1986). Self-reported physical health among aged adults. Journal of Gerontology, 41, 248-260.

McGrath, J. E. (1970). A conceptual formulation for research on stress. In J. E. McGrath (Ed.), Social and psychological factors in stress (pp. 10-21). New York: Holt, Rinehart and Winston.

O'Brien, G. E., \& Feather, N. T. (1990). The relative effects of unemployment and quality of employment on the affect, work values, and personal control of adolescents. Journal of Occupational Psychology, 63, 151-165.

Pearlin, L. I., Menaghan, E., Lieberman, M., \& Mullan, J. (1981). The stress process. Journal of Health and Social Behavior, 22, 337-356.

Price, R. H. (1990). Strategies for managing plant closings and downsizing. In D. Fishman \& C. Cherniss (Eds.), The human side of corporate competitiveness (pp. 127-151). Beverly Hills, CA: Sage.

Prause, J., \& Dooley, D. (1997). Effect of underemployment on school-leaver's self-esteem. Journal of Adolescence, 20, 243 260.

Radloff, L. S. (1977). The CES-D Scale: A self-report depression scale for research in the general population. Applied Psychological Measurement, 1, 385-401.

Rosenberg, M. (1965). Society and the adolescent self-image. Princeton, NJ: Princeton University Press.

Ross, C. E., \& Huber, J. (1985). Hardship and depression. Journal of Health and Social Behavior, 26, 312-327.

Ross, C. E., \& Mirowsky, J. (1995). Does employment affect health? Journal of Health and Social Behavior, 36, 230243.

Ryff, C. D., \& Keyes, C. L. M. (1995). The structure of psychological well-being revisited. Journal of Personality and Social Psychology, 69, 719-727.

Smith, H. L. (1986). Overeducation and underemployment: An agnostic review. Sociology of Education, 59, 85-99.

Sullivan, T. A. (1978). Marginal workers, marginal jobs: The underutilization of American workers. Austin: University of Texas Press.

Sutton, R. I., \& Kahn, R. L. (1986). Prediction, understanding and control as antidotes to organizational stress. In J. Lorsch (Ed.), Handbook of organizational behavior. Boston: Harvard University Press.

Thoits, P. A. (1991). On merging identity theory and stress research. Social Psychology Quarterly, 54, 101-112. 
Vinokur, A. D., Price, R. P., \& Caplan, R. D. (1996). Hard times and hurtful partners: How financial stress affects depression and relationship satisfaction of unemployed persons and their spouses. Journal of Personality and Social Psychology, 71, 166179.

Walsh, D. P. (1995-1996). A new way to classify occupations by education and training. Occupational Outlook Quarterly, 39 (Winter), 29-41.
Warr, P. B. (1987). Work, unemployment, and mental health. New York: Oxford University Press.

Wheaton, B. (1990). Life transitions, role histories, and mental health. American Sociological Review, 55, 209-223.

Zapf, D., Dormann, C., \& Frese, M. (1996). Longitudinal studies in organizational stress research: A review of the literature with reference to methodological issues. Journal of Occupational Health Psychology, 1, 145-169. 